No 3708

Studia nad Autorytaryzmem i Totalitaryzmem 38, nr 1

Wrocław 2016

DOI: $10.19195 / 2300-7249.38 .1 .2$

JACEK DWORZECKI

Wyższa Szkoła Policji w Szczytnie

\title{
The role of the Ministry of Justice and the Ministry of Internal Affairs in the fight against the crime of human trafficking in Poland
}

\section{Introduction}

Clarifications of the International Organization for Migration (Fr. I'Organisation internationale pour les migrations) demonstrate that incidents of trafficking in people, particularly for forced labor are still increasing. Recent years have witnessed $27 \%$ growth in this form of such a serious crime which in the absolute value in terms of the youngest inhabitants of our globe is as follows: 2008 1565 , whereas in $2011-2040$ discovered crimes of human trafficking.

A similar pejorative position is held by the UNICEF. According to its data, about one million of children become the victims of trafficking for sexual reasons every year. In addition, for the last thirty years, annually over 30 million of children have been deprived of their childhood owing to sexual abuse. Trafficking in human beings for forced labor, rightly referred to as contemporary slavery, has become a global problem, reaching beyond the borders of countries and continents.

The crime of trafficking in human beings is an extraordinary situation - in the pejorative sense of the term. The very form of this crime with its high consistency value and international nature, differs significantly from other categories of the most serious crimes, e.g. trafficking in arms, explosives, drugs or stolen jewelry, works of art, etc. Effective combating of trafficking involves another, specific approach by law enforcement agencies which deal with crime detection and prosecution ${ }^{1}$.

${ }^{1}$ M. Lisoň, M. Hullová, 'Organized Crime in the Slovak Republic - Cognition of Criminal Group's Activities', [in:] Selected Aspects of Internal Security, ed. J. Dworzecki, New York 2015, pp. 122-138. 
It is worth remembering that the victims of trafficking in human beings experience not only deprivation of liberty but also violation of inalienable rights including the right to life, right to liberty, respect for private life, prohibition of slavery or any other form of doing forced labor, as well as prohibition of torture and other cruel, degrading or inhuman treatment, not neglecting the principle of non-discrimination in any area of human activity.

Therefore, in the circumstances of detecting a crime of trafficking in human beings, the activities of state institutions established with the aim to repress actions in the framework of crime should possess attributes of high reactivity and focus on detecting and capturing perpetrators, their just and impartial condemning as well as assistance to the victims admissible by the law, including:

- proper victim identification — who is actually a victim, because it is not always obvious;

- discharging victims of criminal liability for committing crimes to which they were forced - e.g. use of counterfeit documents delivered by traffickers at the time of crossing borders;

— privacy law — concealing victim's identity and if needed — also the identity of their immediate family;

- granting entitlement within the range of conducting legal proceedings at the jurisdictional stage;

— providing necessary assistance, e.g. psychological support, physical protection performed by the police, assistance when changing the place of living, material compensation for the personal detriment suffered as well as legal redress, allowing sufficient time for the victims to regain psychophysical balance by law enforcement agencies (through postponement of removal referring to an illegal victim's stay, etc.).

The article outlines the role of the Ministry of Justice and the Ministry of Internal Affairs which owing to their legal and doctrinal obligations deal with the issue of combating crimes of trafficking in human beings in Poland. Legal instruments implemented in order to fight against this form of crime in Poland are also presented. Moreover, the work is also focused on the National Consultation Center for Polish and Foreign Victims of Trafficking.

\section{The laws against the crime of human trafficking in Poland. An introduction to the essence of the problem}

In case of the reform of the Criminal Code of 13 April 2007 which entered into force on 8 June 2010, national authorities providing preparatory proceedings which aimed to identify the offense of trafficking in human beings, could draw only on definitions resulting from the previously cited solutions of international 
law. Thanks to the amendments to the Code, identification of attributes of the offense of trafficking in human beings was based on directives of domestic law

Another addendum concerning the issue of criminalization of trafficking in persons were changes resulting from the Act of 20 May 2010 on the amendment of the Criminal Code, Police Act, the Act on provisions for the implementation of the Criminal Code as well as the cct on the Code of Penal Proceedings which entered into force on 8 September 2010. They introduced essential changes to the provisions referring to the crime of trafficking.

Currently, the Polish Criminal Code criminalizes trafficking and the crime has been standardized in Art. $115 \S 22$ and 23 as well as in Art. 189 a $\S 1$ and $2^{2}$. Furthermore, regulations of the Criminal Code include also other sanctions which explicitly or implicitly refer to this form of prohibited acts, among others: Art. 91 $\S 1$ and 2, Art. 203, Art. $204 \S 1-3$, Art. $211 \mathrm{a}^{3}$.

It is worth indicating that in the Polish system of judicial protection there are many more acts of general application which contain provisions aiming at citizens' protection against the crime of trafficking in human beings or other torts that are related to it. The following regulations can be indicated:

${ }^{2}$ Article $115 \S 22$. Trafficking in human beings means the recruitment, transportation, transfer, harboring, subsequent reception of a person by means of: 1) violence or unlawful threat, 2) abduction, 3) deception, 4) deceitful misleading or use of misleading or inability to properly understand the action being undertaken, 5) abuse of the relationship of dependency, use of a critical situation or helplessness, 6) providing or accepting any financial or personal benefit or its promise to a person who is a primary carer or has authority over the other person in order to abuse him or her even with his or her consent, especially in prostitution, pornography, or other forms of sexual abuse, forced labor, begging, slavery, or other inhuman and degrading forms or in order to obtain cells, tissues or organs which is against the law. If a perpetrator's behavior concerns minors, it represents trafficking in human beings even if methods and measures from points 1-6 have not been involved. Article $115 \S 23$. Slavery is the state of dependency in which a human being is treated like an object of property. Article 189 a $\S 1$. Whoever conducts trade in humans shall be subject to the penalty for a minimum term of three years. Article 189 a $\S 2$. Whoever makes preparations for the offense specified in $\S 1$, shall be subject to imprisonment for 3 months up to 5 years. The Act of 6 June 1997 - the Criminal Code (Journal of Laws of 1997, No 88, item 553).

3 Article $191 \S 1$. Whoever uses violence against a person, or unlawful threat to make another person undertake a specific action, omission or abolition, is subject to the penalty of imprisonment for up to 3 years. Article $191 \S 2$. If an offender acts in the way specified in $\S 1$ to obtain the payment of a claim, he is subject to the penalty of imprisonment for 3 months up to 5 years. Article 203. Whoever, by means of violence, unlawful threat, deception or abusing the relationship of dependency or a critical situation, induces another person to practice prostitution, is subject to the penalty of imprisonment for 1 up to 10 years. Article $204 \S 1$. Whoever, in order to gain a material profit, induces other person to practice prostitution, or facilitates it, is subject to the penalty of imprisonment for 3 months up to 5 years. $\S 2$. Subject to the sentence specified in $\S 1$ is a person who gains material benefit from another person's prostitution. If a person specified in $\S 1$ or 2 is a minor, an offender is subject to the penalty of imprisonment for 1 up to 10 years. Article 211a of the Criminal Code. Whoever, in order to gain a material benefit, organizes the adoption of children against the law, is subject to the penalty of imprisonment for 3 months up to 5 years. The Act of 6 June 1997 - the Criminal Code (Journal of Laws of 1997, No 88, item 553). 
- Constitution of the Republic of Poland of 2 April 1997 passed by the National Assembly on 2 April 1997 and approved by the Nation in the Constitutional Referendum on 25 May, signed by the President of the Republic of Poland on 16 July $1997^{4}$;

- Act of 26 June 1974 - the Labor Code;

- Act of 28 October 2002 on liability of collective entities for acts prohibited under penalty;

- Act of 13 June 2003 on foreigners;

- Act of 9 July 2003 on employment of temporary employees;

- Act of 12 March 2004 on social assistance;

- Act of 20 April 2004 on employment promotion and labor market institutions;

- Act of 1 July 2005 on collection, storage, transplantation of cells, tissues and organs;

- Act of 7 July 2005 on compensation to victims of certain crimes;

- Act of 16 February 2007 on amending the law on social assistance;

- Act of 13 April 2007 on the National Labor Inspectorate;

- Act of 15 June 2012 on the effects of delegating work to foreigners unlawfully residing on the territory of the Republic of Poland;

- Act of 12 December 2013 on foreigners;

Apart from the above-mentioned legal acts, others, both regulating the functioning of formations responsible for security and public order and defining the role of any other administrative bodies or pointing out the duties of local authorities in the development of local community's safety as well as determining gaining support from the state by those who need it, also contribute to preventing and combating the offense of trafficking in human beings in Poland. Hence, the Acts, among others, on the Police, Border Guard, Internal Security Agency, Foreign Intelligence Agency, Audit Office, Penitentiary Service, local government, municipal police, social assistance are essential elements of a national system established to prevent and combat the crime of trafficking in persons.

Properly formed legal instruments which in their extract are responsible for contemporary reality of social life in a certain country (region of the world), are an immanent component of multidisciplinary, synergistic actions undertaken by all the authorities and public institutions for the sake of improvement of the level of widely understood safety.

4 Journal of Laws of 1997, No 78, item 483. For example, Article 24 of the basic law, which provides that "...Labor is subject to protection by the Republic of Poland. A state exercises supervision over working conditions". 


\section{State administration institutions undertaking actions in the fight against trafficking in human beings in Poland. An outline}

Undoubtedly, trafficking in persons belongs to the most complex and multi-faceted forms of crime. This prohibited act - which is difficult to prove is most often committed together with other torts, especially marked by a criminal nature. In order for the discussed practice to be characterized by a satisfactory for the crime world financial gain, it is virtually always linked with the activities of organized crime groups.

Undertaking initiatives targeting this or other forms of organized crime needs to take place in conformity with the synchronization of activities realized by responsible units (with respect to the content) and organizational units that are part of the biggest uniformed forces in our country. Apart from combating, prevention is also a chief topic along with identification of or preliminary reaction to a disclosed perpetrator of trafficking in persons. Except for the Ministry of Internal Affairs and the Ministry of Justice also other departments of state administration as well as public administration bodies, inspection and supervision authorities, autogenous, consultative bodies or non-governmental organizations have ample room for maneuvre in this area. Owing to a limited wording of the following text, it goes on to discuss only the components that form law enforcement agencies in Poland. Police is not included in the work, because a separate, specific text will cover this matter.

\subsection{The Ministry of Justice}

Referring to a strategy on modernization of the area of justice in Poland (for the years 2014-2020) adopted in February 2014, it is worth pointing out its four main objectives:

— improving continuity and stability of the process of modernization in the area of justice;

- multi-criterion view on performance in the area of justice;

- citizen-centered approach in the area of justice;

— defining the basics for the adoption of EU measures in 2014-2020 5 .

The issue of prevention and effective combating crime (victim support and need for perpetrators of crimes to be brought into justice without any delay)

5 Strategy on modernization in the area of justice in Poland for the years 2014-2020 published by the Ministry of Justice, Warsaw 2014, p. 78. The document was prepared by members of a working group, made up of the representatives of the Ministry of Justice, the General Prosecutor's Office, the National School of Judiciary and Public Prosecution, Regional Department of the Penal Service. The text was edited in the Department of Strategy and Deregulation of the Ministry of Justice. 
perceived in the context of social expectations, constitutes an immanent element of the above-mentioned strategy. Among prohibited acts particularly drawing public attention are torts which are explicitly or implicitly linked with trafficking in persons, especially when the victims are the weakest links of all communities, i.e. children, women or other persons with diseases or neuromotor impairments.

Hence, each entity (public, self-governing or non-government etc.) participating in the area of public security, undertakes a range of actions which are supposed to facilitate the improvement of security of all citizens - without exceptions.

Recent important activities that have been performed by support offices of the Minister of Justice which concern combating trafficking in human beings are, among others:

- establishment of the Victim Support and Post-penitentiary Assistance Fund on 1 January 2012 on the basis of regulations of the Act of 12 February 2010 amending the Penal Code, the Executive Penal Code and the Environmental Protection Law. The fund has the status of a special-purpose state fund. Financial resources collected on the fund's accounts which according to Article $43 \S 7$ and 8 of the Executive Penal Code, are generated from salaries of the convicted (deductions of up to $10 \%$ ) are managed by the Minister of Justice. Support is provided to associations, foundations, organizations and other institutions which provide post-penitentiary assistance to prisoners, people leaving penal institutions, detention wards as well as members of their immediate family;

- implementation (reform of the Criminal Code) of provisions of directive 2011/93/EU of the European Parliament and the Council on combating sexual abuse, sexual exploitation of children and child pornography (repealing Council Framework Decision 2004/68/JHA) into the Polish legal system in order to strengthen criminal protection of victims of trafficking in human beings. The reform introduced to the Criminal Code new crimes against sexual freedom and protection standards, particularly concerning children (i.e. Article $197 \S 3$ as well as Article 200 a of the Criminal Code $)^{6}$;

${ }^{6}$ Article $197 \S 1$. Whoever, by using violence, unlawful threat, deceits another person to sexual intercourse, shall be subject to the penalty of the deprivation of liberty for a term of between 2 and 12 years. $\S 2$. If the offender in way specified in $\S 1$ deceits other person to other sexual acts, he is subject to the penalty of imprisonment for a term of between 6 months and 8 years. $\S 3$. Whoever perpetrates rape: 1). he jointly with another person, 2) against a minor below the age of $15,3)$ against any person who is a dependent relative in the descending or ascending line, including adopted children, adoptive parents, brother or sister, is subject to the penalty of imprisonment for a maximum of not less than 3 years. $\S 4$. If a perpetrator of a committed act specified in $\S 1-3$ acts with extreme cruelty, he is subject to the penalty of imprisonment for a maximum of not less than 5 years. Article 200 a $\S 1$. Whoever, for the purpose of committing a crime specified in Article 197 $\S 3$ point 2 or Article 200 , as well as production and record of pornographic content by means of computerized system or telecommunications network shall contact a minor below the age of 15 aiming at deceitful misleading, use of misleading or inability to properly understand undertaken action by a victim, or with the use of unlawful threat and with intention to meet a person, is subject to the penalty of imprisonment for up to 3 years. $\S 2$. Whoever, by means of computerized system 
- carrying out regular training for judges, prosecutors and representatives of other departments of public administration and non-governmental bodies on the protection of the rights of victims;

- editing and distributing training and informative materials concerning the matter of identifying symptoms as proof of the offense of trafficking in human beings or other prohibited acts correlated with the tort.

The tasks of the Department of the Enforcement of Judgments and Probation of the Ministry of Justice include:

- ensuring organization of work of the Head Council for Social Re-adaptation and Convict Support;

— undertaking actions aiming at supporting and developing a system of post-penitentiary assistance;

- handling cases related to the performance of the Victim Support and Post-penitentiary Assistance Fund in the part concerning post-penitentiary assistance;

- taking over matters referring to the pedagogic supervision and superior control of the Minister of Justice exercised over correctional facilities and centers for minors;

- working out solutions relating to the organization and performance of correctional facilities and centers for minors;

- handling cases connected with directing and transferring minors to correctional facilities.

Furthermore, in the structure of the Department of International Cooperation and Human Rights, there is a unit for International Procedures of the Protection of Human Rights.

The tasks in the area of human rights which are completed by employees of the department are:

- tackling cases concerning the participation of the Minister of Justice in the activities of international organizations on the protection of human rights, particularly in the works of the United Nations, the Council of Europe and the Organization for Security and Cooperation in Europe as well as matters regarding the conclusion of international agreements;

- tackling cases aiming at ensuring a proper level (conforming with international standards) of protection of human rights in terms of judiciary, including promotion of texts of the European Court of Human Rights judgments and decisions of other international institutions;

or telecommunications network shall submit a proposal to a minor below the age of 15 , to have a sexual intercourse or sexual assault or participate in producing and recording pornographic content and pursues the objectives, shall be subject to a fine, the penalty of restriction of liberty or the penalty of deprivation of liberty for up to 2 years. The Act of 6 June 1997 — the Criminal Code (Journal of Laws, No 88, item 553). 
- cooperation with the Office of the Minister of Foreign Affairs' Plenipotentiary for Proceedings before International Human Rights Protection Bodies on accusations of violations of human rights by the Polish judiciary and in particular - preparation of analyses and views of the Minister of Justice with regard to the accusations referring to proceedings pending at courts lodged in complaints made to the European Court of Human Rights;

- the analysis and monitoring of judgments of the European Court of $\mathrm{Hu}-$ man Rights with regard to their influence on the legal acts related to the actions of the Minister of Justice;

- preparing reviews and commentaries of the Republic of Poland referring to the execution of international agreements concerning protection of human rights, particularly International Covenant on Civil and Political Rights, the Convention against Torture and Other Cruel, Inhuman and Degrading Treatment or Punishment and the European Convention for the Prevention of Torture or Inhuman or Degrading Treatment or Punishment;

- undertaking actions aiming at supporting and developing the system of assistance provided for victims of crime;

- handling cases related to the performance of the Victim Support and Post-penitentiary Assistance Fund in the part concerning help to persons who become victims of crime, also control over reviews of their merits with the use of grants;

- undertaking and coordinating tasks in terms of the Minister of Justice's action relating to preventing domestic violence, in particular connected with the National Program of Domestic Violence Prevention.

A significant initiative that has recently been introduced (19 May 2014) to a current doctrine of the functioning of the department of justice was the appointment of the Council for Victims of Crime by the Minister of Justice. It belongs to the advisory task of the body comprised of the representatives of the Ministry of Justice, the Ministry of Internal Affairs, Polish Police Headquarters, the General Prosecutor's Office as well as non-governmental institutions to:

- propose practical and organizational solutions that would serve to implement directive of the European Parliament and the EU Council 2012/29/UE of 25 October 2012 establishing minimum standards on the rights, support and protection of victims of crime and replacing Council Framework Decision 2001/220/JHA;

- evaluate drafts of legal acts and proposals of solutions for strengthening the position of crime victims.

Citing statistical data coming from the database of the computer system of the Ministry of Justice and relating to the crime of trafficking, it should be indicated that, for instance, in 2013 in regional courts the total amount of acts from Article 189 a $\S 1$ of the Criminal Code was decided and 23 convictions were 
handed down. Absolute sentences for imprisonment were imposed in case of 19 persons. The execution was conditionally suspended in 3 cases.

Hence, as it is presented in the above-mentioned quasi-statement, in the accepted doctrine of the national judicial decision, we have to do with tough policy, the aim of which is to eliminate threats to a social life coming from persons who have anything to do with trafficking in human beings.

\subsection{The Ministry of Internal Affairs}

The most significant institution of government administration in Poland as far as fighting crime of trafficking in human beings is concerned is the Ministry of Internal Affairs. It is particularly engaged in combating this type of criminal offenses because apart from direct participation in the initiatives of fighting human trafficking, there is also the presence of two uniformed services: Police and Border Guards which report to the Ministry of Internal Affairs and which are responsible for a multidimensional fight with this type of crime in a broad sense and at the highest level. The issue of trafficking in human beings is dealt with by the Migration Policy Department in the Ministry of Internal Affairs.

The responsibilities of the department include substantive and organizational-technical handling of the Panel on Human Trafficking appointed in 2006 which as an organizational unit of the department tackles the issues of introducing legal and organizational solutions in the area of combating and identifying the crime of trafficking in human beings. Furthermore, the department is responsible for cases related to carrying out public tasks in terms of security and public order in the area of human trafficking which are delegated to units not belonging to the public sector of finance and conducting charitable activities.

It is performed in accordance with the Act of 24 April 2003 on public benefit activity and volunteerism ${ }^{7}$. The Ministry of Internal Affairs shall efficiently provide tasks concerning statutory liabilities, in addition it continues to play the role of the leading department in the prevention of trafficking in human beings.

\subsection{The National Consultation Center for Polish and Foreign Victims of Trafficking}

In 2009 a public task concerning managing Consultation Center for Polish and Foreign Victims of Trafficking, delegated to non-governmental organizations by the Minister of Internal Affairs, financed wholly by the state was implemented. Since 2013 the Center has been run by two organizations: La Strada Foundation and the Association HELPful, running two shelters for victims.

\footnotetext{
7 Journal of Laws of 2003, No 96, item 873.
} 
The number of people who were supported within the National Center to some extent presents the scope of trafficking in human beings. From 1 January to 31 December 2013 direct support was given to 222 persons, whereas in 2012 to 198 persons. Out of the total number of 222 people who received help, 103 were Polish citizens and 119 were foreigners. The majority of foreigners who used the support program offered by the center came from Romania (39 persons), Bulgaria (24 persons), Ukraine (20 persons), Vietnam (14 persons) and Philippines (5 persons). Furthermore, support was given to 3 persons from Russia, 2 persons from Cameroon, Kenya, Morocco, Moldavia as well as Uganda, and 1 person from Belarus, the Czech Republic, Slovakia and Sri Lanka. Within the overall number of people who were given support there were 161 women and 61 men. Help from the Center was received by 191 persons of age and 31 minors. The most common forms of exploitation of victims to whom aid was granted include sexual exploitation -105 persons, forced labor -53 persons, forced begging -19 persons.

In 2013, the sum of $250000 €$ was allocated to the performance of tasks by the Center. Moreover, in August 2013 an IT portal devoted entirely to the issue of trafficking in human beings HandelLudzmi.eu was launched. It functions in two language versions: Polish and English. From the time of launching the portal until the end of December 2013, about 86500 of page views and 30000 of unique hits were reported. The portal's website is being updated on a current basis as far as information on the upcoming and past events as well as projects carried out and criminal proceedings in case of trafficking in human beings and victims' rights are concerned. The portal contains practical information about assistance to victims of trafficking in languages such as: English, Russian, Vietnamese, Bulgarian, Romanian. The portal also has its counterpart on a communication network site Facebook, where most recent news from all over the world are reported.

\section{Conclusion}

In order to identify the symptoms and prevent the phenomenon of the crime of trafficking in human beings effectively, there is a need to look at the bigger picture of the issue as well as from the perspective of the role and responsibilities assigned to particular institutions that create the system of internal security in a certain country or region ${ }^{8}$. These units are on the front line as far as the fight against organized crime (which is constantly developing at the same time reaching all fields of social life) is concerned. The positivist work at the grass roots should be particularly indicated. It should consist in:

- increasing the level of citizens' knowledge with use of media and instant messengers about trafficking in human beings, its reasons, effects and mechanisms of criminal activity used to find victims;

\footnotetext{
8 J. Dworzecki, Policja w Polsce. Wybrane zagadnienia, Kraków 2011, pp. 112-189.
} 
- the necessity of verification of currently implemented new more effective instruments of law and doctrine applied in terms of prevention, disclosure and fight against trafficking in human beings and other correlated types of crime;

- introducing regular actions, campaigns and preventive program directed at all social groups aiming at acquainting Poles with the most significant elements of legislature and using mechanisms of combating this type of crime by the state;

- implementing the knowledge on the crime of trafficking in human beings to curriculum realized on all stages of educational system which would undoubtedly contribute to enhancing awareness of potential dangers connected with the presented and discussed issue, especially for the youngest representatives of Polish society.

Undertaking intense, joint actions will have a great impact on strengthening citizens' awareness of potential hazards with regard to trafficking in human beings which will directly contribute to the improvement of security not only of people from Poland but also of the persons who temporarily or permanently stay on the territory of our country.

\section{Bibliography}

The Act of 6 June 1997 — the Criminal Code (Journal of Laws, No 88, item 553).

The Council of Europe Convention on Action against Trafficking in Human Beings, Warsaw, 16 May 2005 (Journal of Laws of 2009, No 20, item 107).

Dworzecki J., Policja w Polsce. Wybrane zagadnienia, Kraków 2011.

Lisoň M., Hullová M., 'Organized Crime in the Slovak Republic - Cognition of Criminal Group's Activities', [in:] Selected Aspects of Internal Security, ed J. Dworzecki, New York 2015. The National Action Plan for Combating Trafficking in Human Beings for the years 2013-2015. Strategy on modernization in the area of justice in Poland for the years 2014-2020 published by the Ministry of Justice, Warsaw 2014.

\section{Internet source}

http://handelludzmi.eu/hl/baza-wiedzy/krajowy-plan-dzialania (obtained: 1.01.2015).

THE ROLE OF THE MINISTRY OF JUSTICE

AND THE MINISTRY OF INTERNAL AFFAIRS IN THE FIGHT

AGAINST THE CRIME OF HUMAN TRAFFICKING IN POLAND

Summary

This article outlines the role of the Ministry of Justice and the Ministry of Internal Affairs which due to their legal and doctrinal obligations deal with the issue of combating the crime of human trafficking in Poland. 
Furthermore, the text presents the concept of human trafficking found in the subject literature as well as legal instruments implemented with a view to combating this form of crime and the characteristics of the National Consultation Centre for Polish and Foreign Victims of Trafficking.

Keywords: human trafficking, Ministry of Justice, Ministry of Internal Affairs, Poland. Jacek Dworzecki

e-mail: j.dworzecki@wspol.edu.pl 